\title{
Seasonal Quality Assessment of Leaves and Stems of Fodder Ligneous Species
}

\section{Zoi M. PARISSI ${ }^{1 *}$, Eleni M. ABRAHAM ${ }^{1}$, Christos ROUKOS ${ }^{2}$, Apostolos P. KYRIAZOPOULOS ${ }^{3}$, Antonios PETRIDIS ${ }^{4}$, Evagelia KARAMERI ${ }^{1}$}

\author{
${ }^{1}$ Aristotle University of Thessaloniki, Department of Forestry and Natural Environment, Laboratory of Range Science (236), 54124 \\ Thessaloniki,Greece; pz@for.auth.gr (*corresponding author); eabraham@for.auth.gr; evikarameri@hotmail.com \\ ${ }^{2}$ Ministry of Rural Development and Food, Regional Department of Epirus \& Western Macedonia, \\ 45445 Ioannina, Greece; roukxris@gmail.com \\ ${ }^{3}$ Democritus University of Thrace, Department of Forestry and Management of the Environment and Natural Resources, \\ 193 Pantazidou str., 68200 Orestiada, Greece; apkyriaz@fmenr.duth.gr \\ ${ }^{4}$ James Hutton Limited (The commercial subsidiary of the James Hutton Institute), Errol Road, Invergowrie, \\ Dundee DD2 5DA, Scotland UK; antonios.petridis@huttonltd.com
}

\begin{abstract}
The objective of this research was to investigate the effect of seasonality on the chemical composition and concentration of phenolic compounds in some ligneous species. The research was conducted at the Aristotle University's farm, Thessaloniki, Greece. From five ligneous species (Robinia pseudoacacia var. monophylla, Amorpha fruticosa, Colutea arborescens, Morus alba and Arbutus unedo) samples (leaves and twigs) were collected during two different seasons (spring and autumn). All samples were analyzed for crude protein (CP), Neutral Detergent Fiber (NDF), Acid Detergent Lignin (ADL) and in vitro dry matter (DM) digestibility (IVDMD), as well as for total phenols (TPH), total tannins (TT) and condensed tannins (CT). The CP content was generally lower and higher in leaves and stems of $A$. unedo and $R$. pseudoacacia, respectively compared to the other tested species. $A$. unedo had the highest values in NDF and ADL in leaves and the highest ADL content in stems. $M$. alba and $C$. arborescens in leaves and $C$. arborescens in stems had the lowest values of ADL content. $M$. alba had the significantly highest value in IVDMD and $A$. unedo the lowest one in both leaves and stems. Season had no significant effect on TPH, TT, and CT of leaves, while in stems they were significantly higher in autumn. A. unedo had the highest concentration of TPH, TT and $R$. pseudoacacia of CT in the leaves. TPH, TT, and CT concentration in stems was significantly higher in A. unedo. According to the findings, the impact of maturation on the type and the concentration of phenols and tannins is species-dependent.
\end{abstract}

Keywords: browse species; Mediterranean region; nutritive value; phenological stage; tannins

Abbreviations: ADL - acid detergent lignin expressed exclusive of residual ash; NDF - neutral detergent fiber expressed inclusive of residual ash; CP - crude protein; DM - dry matter; IVDMD - in vitro DM digestibility; MPTS - Multipurpose trees and shrubs; CT - condensed tannin; TPH - total phenols; TT - total tannins; PVPP - polyvinyl-polypyrrolidone; NTP non-tannin phenols; TAE - tannic acid equivalent; QE - quebracho equivalent.

\section{Introduction}

Multipurpose trees and shrubs (MPTS) could be a valuable alternative green forage source for grazing animals throughout the year (evergreen species) or during critical periods (deciduous ones) (Kokten et al., 2012; Barakat et al., 2013). It is well documented that the leaves and twigs of woody species constitute the main resources in diet of goats grazing in the Mediterranean area (Papachristou and Nastis, 1996; Manousidis et al., 2016). Moreover, the use of branches and leaves for making a foliar fodder is still practiced in many European countries, especially in the Balkan peninsula to provide roughages for livestock during the winter. The usage of browse species' foliage could be efficiently contributed to the reduction of ruminal methanogenesis in livestock species fed low-quality forage diets and to improve their performance (Delgado et al., 2012). 
However, their potential as feed resources by herbivores is often restricted by defending or deterring mechanisms related to phenolic compounds (particularly high condensed tannin (CT) content) (Provenza, 1995; Rubanza et al., 2003; Bakshi and Walhwa, 2004; Sallam et al., 2010) which decrease feed intake, nutrient digestibility and nitrogen retention (Kumar and Vaithiyanathan 1990; Silanikove et al., 1996; Bansi et al., 2014). Tannins have differential effects (Rana et al., 2006) on animals ranging from beneficial to toxicity and even death (Makkar, 2003a) mainly depending on their concentration and nature. Thus, Lotus corniculatus (CT 18-29 $\mathrm{g} \mathrm{kg}^{-1} \mathrm{DM}$ ) in ewes' diet it was found to increase animal productivity and reproduction efficiency (Min et al., 2001; Ramirez-Restreppo et al., 2005), while Lotus pedunculatus (CT content $>50 \mathrm{~g} \mathrm{~kg}^{-1} \mathrm{DM}$ ) had a negative effect on voluntary feed intake of grazing sheep (Barry and McNabb, 1999). Moreover, consumption of Terminalia oblongata leaves with high hydrolysable tannins concentration caused poisoning of sheep (McSweeney et al., 2001).

Chemical composition of woody species is significantly influenced by season (Evans, 1989; Singh and Todaria, 2012) and the nutritive value is generally decreased due to physiological changes during the growing season (Al-Masri, 2013). This decrease over the growing season is mainly attributed to the dilution effect. It is known that leaves contain more than $40 \%$ of the total nitrogen in a browse species (Kramer and Kozlowski, 1979) and their nutritive value is higher compared to the stems (Cordesse et al., 1991). This difference in their quality is became higher as the plant matures. Similarly, the concentration of tannins is influenced by maturity stage, leaf age and and/or collection season and proportion of sample's foliage (Schultz et al., 1982; Rogler and Sell, 1984; Salem, 2005). For instance, Paul et al. (1991) found higher total extractable phenols in younger leaves of Quercus semecarpifolia in comparison to old ones.

Browse species have been studied from many researchers especially in the Mediterranean region as they are essential components of the native vegetation (Gilboa et al., 2000; Corleto et al., 2009). These species either indigenous as Quercus coccifera, Fraxinus ornus, Carpinus orientalis, Arbutus unedo, Colutea arborescens or introduced as Robinia pseudoacacia, Morus alba, Amorpha fruticosa (Papachristou and Papanastasis, 1994; Papachristou et al., 1999; Parissi, 2001; Roukos 2016) are characterized as valuable feed resource for livestock. However, there is limited research conducted on the effect of growth stage, particularly in relation to the anti-nutritional components in leaves and stems of browses used as a feed for ruminants. Therefore, the objective of this research was to investigate the effect of seasonality (vegetative and maturity stage) on the chemical composition and concentration of phenolic compounds in leaves and stems of some ligneous species.

\section{Materials and Methods}

Study area and plant materials

Five ligneous species [the deciduous leguminous species Robinia pseudoacacia var. monophylla (L.) (R.ps.), Amorpha fruticosa L. (A.fr.), Colutea arborescens L. (C.ar.), the deciduous Morus alba L. (M.al.), and the evergreen Arbutus unedo L. (A.un.)] were investigated in this study. All species were kept in a shrubby form as they cut in $60 \mathrm{~cm}$ height every January. All browse samples were been harvested from plantations in Aristotle University's farm $\left(40^{\circ} 34^{\prime} \mathrm{E}, 23^{\circ} 43^{\prime}\right.$ $\mathrm{N}$, at sea level) in northern Greece. The climate of the area is defined as Mediterranean semiarid with cold winters. The mean annual temperature and precipitation are $15.5^{\circ} \mathrm{C}$ and $443 \mathrm{~mm}$, respectively.

\section{Sample collection and chemical analyses}

Samples were hand-plucked in 2009 (i.e., leaves and twigs with diameter $<3 \mathrm{~mm}$ ) from three individual plants per species at two different periods and stages of maturity as follows: (i) during the season of rapid growth (immature: May, IM) when the leaves were young, and (ii) in September (mature: September, M) when growth had ceased and the woody parts had been hardened. Upon collection, each plant sample was divided into leaves and stems and oven-dried at $50{ }^{\circ} \mathrm{C}$ for $48 \mathrm{~h}$. All samples were ground through a $1 \mathrm{~mm}$ sieve and were analyzed for $\mathrm{N}$ using a Kjeldahl procedure (method 2001.11 of the AOAC, 2002 ) and crude protein (CP) was calculated as $\mathrm{N}$ content $\times 6.25$. Plant fiber analysis was performed according to the method of Van Soest et al. (1991), for Neutral Detergent Fiber (NDF) and Acid Detergent Lignin (ADL).

The analyses for total phenols (TPH), total tannins (TT) and condensed tannins (CT) were completed in three replicates according to Makkar (2003b). For the plant extraction, approximately $200 \mathrm{mg}$ of ground plant sample was been weighed and inserted in a $25 \mathrm{ml}$ glass tube. $10 \mathrm{ml}$ of aqueous acetone (70\%) added to the tube and suspended in an ultrasonic water bath for $20 \mathrm{~min}(2 \times 10 \mathrm{~min}$, with 5 min break) at room temperature. Subsequently, the tube was been centrifuged for $10 \mathrm{~min}$ at $3000 \times \mathrm{g}$ at $4^{\circ} \mathrm{C}$ and the supernatant was collected. This procedure repeated three times per sample. The TPH and TT determined by a modified Folin-Ciocalteu method using polyvinyl-polypyrrolidone (PVPP) to separate tannin phenols from nontannin phenols (NTP). Between 0.02 and $0.1 \mathrm{ml}$ of the extract (depending on the concentration of TP and TT in the plant sample) was put in a test tube and filled up to the volume of $0.5 \mathrm{ml}$ with distilled water. Folin-Ciocalteu reagent $(0.25 \mathrm{ml} ; 1 \mathrm{~N}$; Sigma-Aldrich Chemie $\mathrm{GmbH}$, Steinheim, Germany) and $1.25 \mathrm{ml}$ sodium carbonate solution ( $40 \mathrm{~g} \mathrm{Na}_{2} \mathrm{CO}_{3} \cdot 10 \mathrm{H}_{2} \mathrm{O}$ in $200 \mathrm{ml}$ distilled water) were added. The tube was vortexed and absorbance for TP was been recorded at $725 \mathrm{~nm}$ after $40 \mathrm{~min}$ using a UV-vis spectrophotometer. For measuring TT, $100 \mathrm{mg}$ PVPP (Sigma-Aldrich Chemie GmbH, Steinheim, Germany) in a test tube was added by $1.0 \mathrm{ml}$ distilled water and $1.0 \mathrm{ml}$ of the extract. The mixture was vortexed and kept at $4{ }^{\circ} \mathrm{C}$ for $15 \mathrm{~min}$, centrifuged $\left(3000 \times \mathrm{g}, 4^{\circ} \mathrm{C}, 10 \mathrm{~min}\right)$, and the supernatant, containing only the NTP, was decanted. Measurement of the phenolic content of the supernatant was as described above. Both TP and TT were calibrated against tannic acid solution as a standard (Sigma-Aldrich Chemie GmbH, Steinheim, Germany) and values as tannic acid equivalent (mg/g TAE) (Makkar et al., 1993). Condensed tannins (CT) were determined according to the method of Porter et al. (1986), using purified quebracho as the reference standard and therefore expressed as quebracho equivalent $(\mathrm{QE})$. 
428

In vitro dry matter (DM) digestibility (IVDMD) of the species was determined using a modification of Moore's (1970) and Harris' (1970), Tilley and Terry (1963) two stage digestion method. The rumen liquor was obtained from three ruminally fistulated goats grazing in rangelands, with free access to drinking water and mineral licks. Rumen liquid was collected before the morning meal in thermoflasks.

\section{Statistical analyses}

Two-way ANOVA of data was performed using SPSS ${ }^{\circ}$ statistical software v. 18.0 (SPSS Inc., Chicago, IL, USA) in order to determine the differences among the tested species in the two stage of maturity in leaves and stems. The Least Significant Difference (LSD) at the 0.05 probability level was used to detect the differences among means (Steel and Torrie, 1980).

\section{Results}

The season significantly affected NDF, ADL and CP contents as well as the IVDMD of leaves and stems in the tested species (Tables 1 and 2). In autumn, the NDF and ADL content for both leaves and stems increased, while CP and IVDMD decreased significantly. The increase of NDF and ADL in autumn was more important in stems than leaves. Particularly, the ADL content of stems in autumn was on average $85 \%$ more than in spring, while in leaves was only $15 \%$. As a consequence, the IVDMD decreased on average in leaves only by $5 \%$ in autumn but in stems by $40 \%$.

Significant differences in NDF, ADL, CP and IVDMD

(Tables 1 and 2) were recorded for both leaves and stems among the tested species across season. In particular, the CP content was generally lower and higher in leaves and stems of $A$. unedo and $R$. pseudoacacia respectively compared to the other tested species (Tables 1 and 2). The CP content ranged from 101 to $273 \mathrm{~g} \mathrm{~kg}^{-1} \mathrm{DM}$ (Table 1) in leaves, while from 80 to $147 \mathrm{~g} \mathrm{~kg}^{-1} \mathrm{DM}$ in stems (Table 2).

Arbutus unedo had the significantly highest values of NDF and ADL in leaves and the highest ADL content in stems. NDF content in stems of $A$. unedo and $C$. arborescens were higher than $R$. pseudoacacia and $A$. fruticosa. On the other hand, the lowest values of NDF were recorded in $M$. alba and $A$. fruticosa in leaves and stems respectively. Regarding the ADL, M. alba and C. arborescens in leaves and C. arborescens in stems had the lowest values. Finally, $M$. alba had the significantly higher value in IVDMD and $A$. unedo the lower one in both leaves and stems. Significant interactions were observed between the season and the tested species for all nutritive parameters, with the exception of IVDMD in leaves (Tables 1 and 2), indicating that the effect of season was not consistent for all the species. The NDF content in leaves of $A$. fruticos $a$ and of $C$. arborescens did not significantly differ between autumn and spring (Fig. 1).

Similarly, the ADL and CP content in leaves of $M$. alba (Fig. 1), the CP of C. arborescens and of A. unedo (Fig. 1)

Table 1. The effect of season and species on chemical composition $\left(\mathrm{g} \mathrm{kg}^{-1} \mathrm{DM}\right)$ and IVDMD $\left(\mathrm{g} \mathrm{kg}^{-1} \mathrm{DM}\right)$ of browsed leaves (mean $\left.\pm \mathrm{SE}\right)$

\begin{tabular}{|c|c|c|c|c|}
\hline Season & $\mathrm{CP}\left(\mathrm{g} \mathrm{kg}^{-1} \mathrm{DM}\right)$ & $\mathrm{NDF}\left(\mathrm{g} \mathrm{kg}^{-1} \mathrm{DM}\right)$ & $\mathrm{ADL}\left(\mathrm{g} \mathrm{kg}^{-1} \mathrm{DM}\right)$ & IVDMD $\left(\mathrm{g} \mathrm{kg}^{-1} \mathrm{DM}\right)$ \\
\hline Spring & $247 \pm 25 a^{*}$ & $276 \pm 26 b$ & $61 \pm 12 b$ & $590 \pm 6 a$ \\
\hline Autumn & $187 \pm 16 b$ & $307 \pm 31 \mathrm{a}$ & $70 \pm 12 \mathrm{a}$ & $560 \pm 6 b$ \\
\hline \multicolumn{5}{|l|}{ Species } \\
\hline Robinia pseudoacacia & $273 \pm 30 a$ & $266 \pm 15 c$ & $56 \pm 7 c$ & $572 \pm 14 c$ \\
\hline Amorpha fruticosa & $232 \pm 43 b c$ & $327 \pm 6 b$ & $97 \pm 2 b$ & $454 \pm 12 d$ \\
\hline Morus alba & $219 \pm 3 c$ & $211 \pm 13 \mathrm{~d}$ & $32 \pm 1 d$ & $811 \pm 14 a$ \\
\hline Arbutus unedo & $108 \pm 12 d$ & $436 \pm 19 a$ & $115 \pm 4 a$ & $319 \pm 10 \mathrm{e}$ \\
\hline Colutea arborescens & $254 \pm 9 \mathrm{ab}$ & $219 \pm 5 d$ & $28 \pm 3 d$ & $718 \pm 32 b$ \\
\hline \multicolumn{5}{|l|}{ Source of variation } \\
\hline Season $(\mathrm{A})$ & $\mathrm{P}<0.05$ & $\mathrm{P}<0.05$ & $\mathrm{P}<0.05$ & $\mathrm{P}<0.05$ \\
\hline Species (B) & $\mathrm{P}<0.05$ & $\mathrm{P}<0.05$ & $\mathrm{P}<0.05$ & $\mathrm{P}<0.05$ \\
\hline $\mathrm{A} \times \mathrm{B}$ (Interaction) & $\mathrm{P}<0.05$ & $\mathrm{P}<0.05$ & $\mathrm{P}<0.05$ & ns \\
\hline
\end{tabular}

Table 2. The effect of season and species on chemical composition $\left(\mathrm{g} \mathrm{kg}^{-1} \mathrm{DM}\right)$ and IVDMD $\left(\mathrm{g} \mathrm{kg}^{-1} \mathrm{DM}\right)$ of browsed stems (mean $\left.\pm \mathrm{SE}\right)$

\begin{tabular}{|c|c|c|c|c|}
\hline Season & $\mathrm{CP}\left(\mathrm{g} \mathrm{kg}^{-1} \mathrm{DM}\right)$ & $\mathrm{NDF}\left(\mathrm{g} \mathrm{kg}^{-1} \mathrm{DM}\right)$ & $\mathrm{ADL}\left(\mathrm{g} \mathrm{kg}^{-1} \mathrm{DM}\right)$ & IVDMD $\left(\mathrm{g} \mathrm{kg}^{-1} \mathrm{DM}\right)$ \\
\hline Spring & $149 \pm 18 \mathrm{a}$ & $581 \pm 19 b^{*}$ & $78 \pm 10 b$ & $580 \pm 51 a$ \\
\hline Autumn & $78 \pm 5 b$ & $692 \pm 5 a$ & $145 \pm 13 a$ & $351 \pm 30 \mathrm{~b}$ \\
\hline \multicolumn{5}{|l|}{ Species } \\
\hline Robinia pseudoacacia & $147 \pm 36 a$ & $616 \pm 58 b$ & $117 \pm 33 b$ & $478 \pm 103 b$ \\
\hline Amorpha fruticosa & $122 \pm 22 \mathrm{a}$ & $612 \pm 49 b$ & $125 \pm 31 b$ & $498 \pm 32 b$ \\
\hline Morus alba & $137 \pm 36 a$ & $633 \pm 34 \mathrm{ab}$ & $92 \pm 17 \mathrm{c}$ & $617 \pm 94 a$ \\
\hline Arbutus unedo & $80 \pm 14 b$ & $663 \pm 10 a$ & $155 \pm 11 \mathrm{a}$ & $277 \pm 27 c$ \\
\hline Colutea arborescens & $81 \pm 4 b$ & $659 \pm 16 a$ & $69 \pm 6 d$ & $458 \pm 80 b$ \\
\hline \multicolumn{5}{|l|}{ Source of variation } \\
\hline Season $(\mathrm{A})$ & $\mathrm{P}<0.05$ & $\mathrm{P}<0.05$ & $\mathrm{P}<0.05$ & $\mathrm{P}<0.05$ \\
\hline Species (B) & $\mathrm{P}<0.05$ & $\mathrm{P}<0.05$ & $\mathrm{P}<0.05$ & $\mathrm{P}<0.05$ \\
\hline $\mathrm{A} \times \mathrm{B}$ (Interaction) & $\mathrm{P}<0.05$ & $\mathrm{P}<0.05$ & $\mathrm{P}<0.05$ & $\mathrm{P}<0.05$ \\
\hline
\end{tabular}

${ }^{*}$ Means followed by the same letter in the column for each independent variable did not significantly differ $(\mathrm{P}>0.05) ;{ }^{* *}$ ns: not significant. 


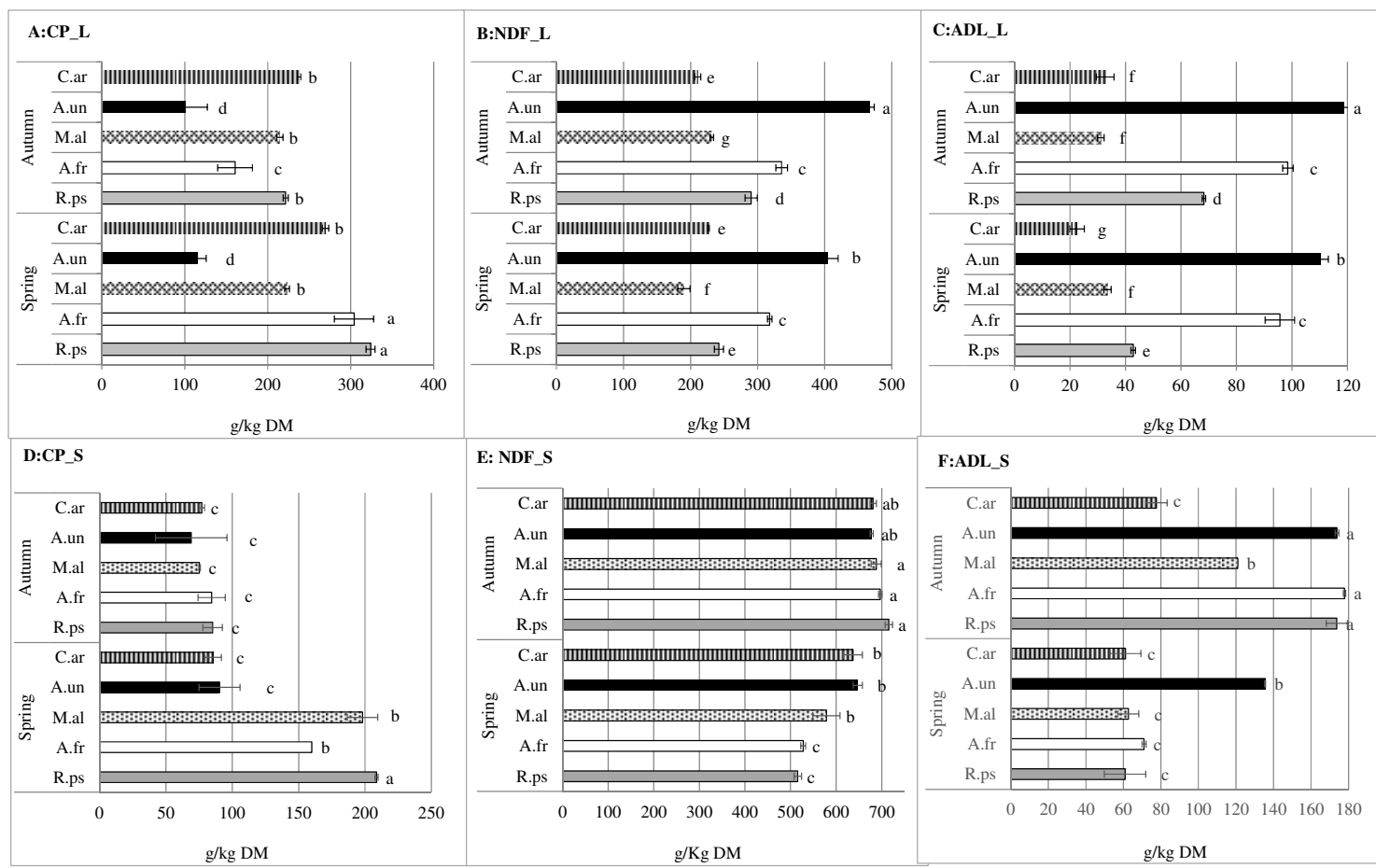

Fig. 1. Interactions between season $\times$ browse species for CP $\left(\mathrm{g} \mathrm{kg}^{-1} \mathrm{DM}\right), \mathrm{NDF}\left(\mathrm{g} \mathrm{kg}^{-1} \mathrm{DM}\right)$ and ADL $\left(\mathrm{g} \mathrm{kg}^{-1} \mathrm{DM}\right)$ content, for leaves (L) and stems (S). R.ps.: Robinia pseudoacacia, A.fr.: Amorpha fruticosa, C.ar., Colutea arborescens, M.al.: Morus alba, A.un.: Arbutus unedo. ${ }^{*}$ Means followed by the same letter for the same content did not significantly differ $(\mathrm{P}>0.05)$.

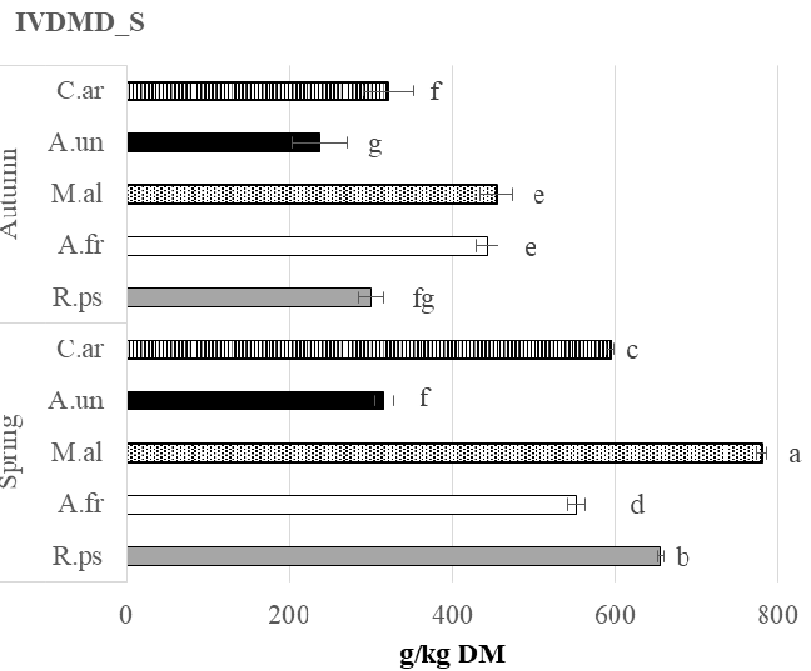

Fig. 2. Interaction between browse species and growth stage of IVDMD ( $\left.\mathrm{g} \mathrm{kg}^{-1} \mathrm{DM}\right)$ in stems (S). R.ps.: Robinia pseudoacacia, A.fr.: Amorpha fruticosa, C.ar., Colutea arborescens, M.al.: Morus alba, A.un.: Arbutus unedo

and the ADL content of $A$. fruticosa did not significantly differ between autumn and spring. No differences were detected between seasons in the CP and NDF contents in stems of $C$. arborescens and $A$. unedo and in the ADL stem content of $C$. arborescens (Fig. 1). Finally, the IVDMD of $M$. alba in stems was significantly higher in spring and autumn, followed by $R$. pseudoacacia in spring and $A$. fruticosa in autumn (Fig. 2).

Season had no significant effect on TPH, TT, and CT of leaves of the tested species, while it significantly affected the content of the stems (Tables 3 and 4). The TPH, TT, and CT concentrations of stems were significantly higher in autumn compared to spring. Overall, species had significant effect in both TPH, TT, and CT concentration of leaves and stems. Particularly, $A$. unedo had the highest concentration of TPH, TT in the leaves compared to the other species followed by $R$. pseudoacacia and $A$. fruticosa.

On the other hand, $R$. pseudoacacia had the highest concentration of CT in the leaves compared to that of the other species followed by $A$. fruticosa and Ar. unedo. Regarding the TPH, TT and CT concentrations in stems, these were significantly higher in $A$. unedo followed by $A$. fruticosa, compared to the others. In all cases, the lowest values were recorded in $C$. arborescens and $M$. alba (Tables 3 and 4). It has also noticed that in all tested species the concentration of TPH, TT, and CT was much lower in stems than in leaves.

There was a significant interaction between season $x$ species for TPH, TT and CT (Table 5) for both leaves and stems. The TPH and TT concentrations in leaves of $R$. pseudoacacia and the TPH of $M$. alba were significantly lower in autumn compared to spring (Table 5), while there were not significant differences between spring and autumn for all the other species.

On the other hand, the CT concentration in leaves of $R$. pseudoacacia and $A$. fruticosa decreased significantly, while this of $A$. unedo increased from spring to autumn. The concentration of TPH, TT and CT in stems of all the tested species generally was immutable or decreased from spring to autumn except of $A$. unedo that was significantly increased (Table 5). Based on their chemical composition, IVDMD and the concentration of condensed tannins the browse species could be ranked as follow: $M$. alba $>R$. pseudoacacia $>C$. arborescens $>A$. fruticosa $>A$. unedo. 
430

Table 3. TPH ( $\mathrm{mgg}^{-1} \mathrm{DM}$ TAE), TT ( $\mathrm{mgg}^{-1} \mathrm{DM}$ TAE), CT ( $\mathrm{mgg}^{-1} \mathrm{DM}$ QE) concentration in leaves as affected by browse species and growth (mean \pm SE)

\begin{tabular}{|c|c|c|c|}
\hline Season & TPH $\left(\mathrm{mgg}^{-1}\right.$ DM TAE $)$ & TT $\left(\mathrm{mgg}^{-1}\right.$ DM TAE $)$ & $\mathrm{CT}\left(\mathrm{mgg}^{-1}\right.$ DM QE $)$ \\
\hline Spring & $19 \pm 2 \mathrm{a}^{*}$ & $15 \pm 1 a$ & $38 \pm 6 a$ \\
\hline Autumn & $18 \pm 2 \mathrm{a}$ & $14 \pm 1 \mathrm{a}$ & $34 \pm 5 a$ \\
\hline \multicolumn{4}{|l|}{ Species } \\
\hline Robinia pseudoacacia & $23 \pm 1 b$ & $20 \pm 1 b$ & $92 \pm 5 \mathrm{a}$ \\
\hline Amorpha fruticosa & $17 \pm 1 c$ & $15 \pm 1 \mathrm{c}$ & $54 \pm 5 b$ \\
\hline Morus alba & $9 \pm 1 d$ & $6 \pm 0.4 \mathrm{~d}$ & $1 \pm 0.03 \mathrm{~d}$ \\
\hline Arbutus unedo & $34 \pm 1 a$ & $28 \pm 1 a$ & $32 \pm 4 c$ \\
\hline Colutea arborescens & $7 \pm 0.3 \mathrm{~d}$ & $4 \pm 0.2 \mathrm{~d}$ & $1 \pm 0.07 \mathrm{~d}$ \\
\hline \multicolumn{4}{|l|}{ Source of variation } \\
\hline Season $(\mathrm{A})$ & ns & ns & ns \\
\hline Species $(\mathrm{B})$ & $\mathrm{P}<0.05$ & $\mathrm{P}<0.05$ & $\mathrm{P}<0.05$ \\
\hline AXB (Interaction) & $\mathrm{P}<0.05$ & $\mathrm{P}<0.05$ & $\mathrm{P}<0.05$ \\
\hline
\end{tabular}

Table 4. TPH ( $\mathrm{mgg}^{-1} \mathrm{DM}$ TAE), TT ( $\mathrm{mgg}^{-1} \mathrm{DM}$ TAE), CT $\left(\mathrm{mgg}^{-1} \mathrm{DM} \mathrm{QE}\right)$ concentration in stems as affected by browse species and growth stage (mean \pm SE)

\begin{tabular}{|c|c|c|c|}
\hline Season & $\mathrm{TPH}\left(\mathrm{mgg}^{-1} \mathrm{DM}\right.$ TAE $)$ & $\mathrm{TT}\left(\mathrm{mgg}^{-1} \mathrm{DM}\right.$ TAE $)$ & $\mathrm{CT}\left(\mathrm{mgg}^{-1} \mathrm{DM} \mathrm{QE}\right)$ \\
\hline Spring & $7 \pm 0.8 b^{*}$ & $5 \pm 0.6 b$ & $10 \pm 1 b$ \\
\hline Autumn & $9 \pm 1 \mathrm{a}$ & $6 \pm 1 \mathrm{a}$ & $15 \pm 2 a$ \\
\hline \multicolumn{4}{|l|}{ Species } \\
\hline Robinia pseudoacacia & $5 \pm 1 c$ & $4 \pm 1 c$ & $13 \pm 5 c$ \\
\hline Amorpha fruticosa & $9 \pm 0.6 \mathrm{~b}$ & $6 \pm 0.4 b$ & $18 \pm 2 b$ \\
\hline Morus alba & $4 \pm 0.3 c$ & $2 \pm 0.3 \mathrm{~d}$ & $2 \pm 0.4 \mathrm{~d}$ \\
\hline Arbutus unedo & $19 \pm 1 \mathrm{a}$ & $15 \pm 1 \mathrm{a}$ & $30 \pm 4 a$ \\
\hline Colutea arborescens & $4 \pm 0.3 c$ & $2 \pm 0.3 \mathrm{~d}$ & $0.4 \pm 0.01 d$ \\
\hline \multicolumn{4}{|l|}{ Source of variation } \\
\hline Season $(\mathrm{A})$ & $\mathrm{P}<0.05$ & $\mathrm{P}<0.05$ & $\mathrm{P}<0.05$ \\
\hline Species (B) & $\mathrm{P}<0.05$ & $\mathrm{P}<0.05$ & $\mathrm{P}<0.05$ \\
\hline AXB (Interaction) & $\mathrm{P}<0.05$ & $\mathrm{P}<0.05$ & $\mathrm{P}<0.05$ \\
\hline
\end{tabular}

${ }^{*}$ Means followed by the same letter in the column for each independent variable did not significantly differ $(\mathrm{P}>0.05) ;{ }^{* *}$ ns: not significant.

Table 5. Interaction between browse species and growth stage of TPH ( $\mathrm{mgg}^{-1} \mathrm{DM}$ TAE), TT ( $\left.\mathrm{mgg}^{-1} \mathrm{DM} \mathrm{TAE}\right), \mathrm{CT}\left(\mathrm{mgg}^{-1} \mathrm{DM}\right.$ QE) concentration in leaves and stems $($ mean \pm SE)

\begin{tabular}{|c|c|c|c|c|c|c|c|}
\hline \multirow{2}{*}{ Season } & \multirow{2}{*}{$\begin{array}{c}\text { Species } \\
\text { (abbrev.) }\end{array}$} & \multicolumn{3}{|c|}{ Leaves } & \multicolumn{3}{|c|}{$\underline{\text { Stems }}$} \\
\hline & & TPH & TT & CT & TPH & TT & CT \\
\hline \multirow{5}{*}{ Spring } & R.ps. & $27 \pm 1.1 b$ & $23 \pm 1.2 b$ & $101 \pm 3.5 \mathrm{a}$ & $6 \pm 0.4 e$ & $4 \pm 0.3 \mathrm{~d}$ & $17 \pm 0.8 b$ \\
\hline & A.fr. & $16 \pm 1.3 \mathrm{~d}$ & $14 \pm 1.1 \mathrm{c}$ & $68 \pm 7.6 \mathrm{c}$ & $10 \pm 0.7 \mathrm{c}$ & $7 \pm 0.5 c$ & $16 \pm 1.7 b$ \\
\hline & M.al. & $11 \pm 1.6 \mathrm{e}$ & $7 \pm 0.4 \mathrm{~d}$ & $1 \pm 0.03 f$ & $4 \pm 0.3 \mathrm{fg}$ & $2 \pm 0.2 \mathrm{ef}$ & $0.5 \pm 0.05 \mathrm{e}$ \\
\hline & A.un. & $34 \pm 2.1 \mathrm{a}$ & $28 \pm 1.8 \mathrm{a}$ & $16 \pm 2.2 \mathrm{e}$ & $16 \pm 1.0 \mathrm{~b}$ & $12 \pm 0.7 b$ & $18 \pm 2.8 b$ \\
\hline & C.ar. & $7 \pm 0.3 f$ & $4 \pm 0.2 \mathrm{~d}$ & $1 \pm 0.05 f$ & $3 \pm 0.2 \mathrm{~g}$ & $1 \pm 0.2 f$ & $0.4 \pm 0.02 \mathrm{e}$ \\
\hline \multirow{5}{*}{ Autumn } & R.ps. & $20 \pm 0.7 \mathrm{c}$ & $16 \pm 0.7 \mathrm{c}$ & $83 \pm 7.4 b$ & $4 \pm 0.3 \mathrm{fg}$ & $3 \pm 0.2 \mathrm{e}$ & $9 \pm 0.8 \mathrm{c}$ \\
\hline & A.fr. & $18 \pm 1.2 \mathrm{~cd}$ & $15 \pm 1.1 \mathrm{c}$ & $40 \pm 4.1 \mathrm{~d}$ & $8 \pm 0.9 \mathrm{~d}$ & $5 \pm 0.6 \mathrm{~d}$ & $20 \pm 3.2 b$ \\
\hline & M.al. & $7 \pm 0.6 f$ & $4 \pm 0.5 \mathrm{~d}$ & $1 \pm 0.1 f$ & $4 \pm 0.5 \mathrm{fg}$ & $3 \pm 0.4 \mathrm{e}$ & $3 \pm 0.6 \mathrm{~d}$ \\
\hline & A.un. & $36 \pm 1.9 \mathrm{a}$ & $29 \pm 1.6 \mathrm{a}$ & $48 \pm 1.0 \mathrm{~d}$ & $22 \pm 1.4 a$ & $18 \pm 1.3 \mathrm{a}$ & $43 \pm 2.5 \mathrm{a}$ \\
\hline & C.ar. & $8 \pm 0.5 f$ & $4 \pm 0.3 \mathrm{~d}$ & $1 \pm 0.1 \mathrm{f}$ & $5 \pm 0.3 f$ & $3 \pm 0.3 e$ & $0.4 \pm 0.01 \mathrm{e}$ \\
\hline
\end{tabular}

${ }^{*}$ Means followed by the same letter in each column for the same independent variable did not significantly differ $(\mathrm{P}>0.05)$.

\section{Discussion}

The nutritive parameters of the tested species in both leaves and stems were varied related to the season. The CP contents of the leaves and stems of the investigated species during the spring season were significantly higher than those harvested in autumn. It is well known that the decrease in $\mathrm{CP}$ content is due to the thickness of the cell walls in the maturity stage (Blair et al., 1981; Holechek et al., 1989). However, this decrease was sharper in stems than in leaves, because they had higher content of CP compared to stem during both seasons (Ball et al., 2001). Generally, more than the $40 \%$ of the total $N$ (Kramer and Kozlowski, 1979) is found in leaves of the ligneous plant species, and thus they have higher concentration of CP compared to stems (Holechek et al., 1989; Mero and Uden, 1997).

The higher CP content of the leguminous species is expected as they usually contain 25 to $50 \%$ more CP than non-leguminous ones (Cheeke, 1992; Jamala et al., 2013). Papachristou and Papanastasis (1994) investigated 10 woody fodder species and found similar CP contents for $R$. pseudoacacia and $C$. arborscens. Crude protein is a good indicator to determine the quality of forage (Amiri and Mohamed Shariff, 2012). According to the results of CP in 
the tested species it could exceed the demands of small ruminants for maintenance and lactation except $A$. unedo that cover only for maintenance (NRC, 1981, 1985). Despite the fact that $M$. alba had lower CP content than the leguminous species, this content was relatively high and thus M. alba was suggested by Dwi Yulistiani et al. (2015) as a supplement source to provide fermentable energy and fermentable protein to rice straw diet.

On the other hand, NDF and ADL contents were increased due to maturation in both leaves and stems. $A$. unedo and $R$. pseudoacacia had the higher increment in their NDF and ADL content in autumn. On the contrary, $M$. alba and C. arborescens had the lower one. The average chemical composition of the three leguminous species is consistent to the findings of Papachristou and Papanastasis (1994), while Khazaal et al. (1993) reported similar results for $A$. unedo. Moreover, these results are in agreement with other researchers worked on seasonal effect to the nutritive value of fodder species (Kamalak, 2006; Kokten et al., 2012). In addition, NDF and ADL contents in stems were higher than in leaves. Similar results have been found by Griffin and Jung (1983) and Pootaeng-on et al. (2015). Season had a different effect on the tested species due to the high variability in the nutrient content among the browse species. This variability could be attributed to the species variability owing to factors such as plant part, morphological differences within the same species, season harvesting etc. (Solomon 2001; Beyene, 2009). These results are in agreement with findings for browse species reported by Shenkute et al. (2012).

The lower IVDMD during autumn was expected as the proportion of structural carbohydrates in the plant increases with maturity. Thus, the cell walls contents and the digestibility decreased (Van Soest, 1982). Moreover, the in vitro digestibility of the stems was lower compared to the leaves, as they had higher NDF and ADL content than leaves. Stems were less digestible compared to the leaves at advanced maturity as lignin deposition in the cell walls increased with maturation (McDonald et al., 1995). Additionally, leaves are $20 \%$ more digestible than stems (Cordesse et al., 1991). Morus alba seems to be a valuable species as a feed for small ruminants as it had relatively high CP content and IVDMD. The results of the present study confirm previous reports conducted on the same species (Parissi, 2003; Dwi Yulistiani et al., 2015). On the other hand, $A$. unedo has very low IVDMD. Conversely, Hajer $e t$. al. (2004) referred relatively higher IVDMD (64\%) in spring for the same species, while the chemical composition was similar to the present study.

The concentration of TPH, TT and CT in leaves was not different between spring and autumn. Conversely, the concentration of TPH, TT and CT in stems was increased from spring to autumn. Contrasting results have been reported about the concentration of phenols in relation to the maturity stage. In a previous study, Glyphis and Puttick (1988) referred that the concentration of phenols increased or remained stable as leaves became more mature. A. unedo had the higher concentration of all species in both leaves and stems followed by the two leguminous species $R$. pseudoacacia and $A$. fruticosa. These species could be defined as tanniniferous species because of their high CT compared to the other species (Parissi et al., 2014). The presence of secondary metabolites as tannins in these species probably contributed to their higher ADL content in leaves. The high concentration of condensed tannins in the legumes species is measured as lignin (pseudo lignin) (MuellerHarvey and McAllan, 1992) and leads to its overestimation. Koukoura and Nastis (1994) have recorded similar results for the total phenols concentration of all the above tested species as a whole plant sample. Leaves had higher concentration of TPH, TT and CT than stems in both maturity stages. Similarly, Salawu et al. (1997) reported that the leguminous species Calliandra calothyrsus had more CT in leaves than in stems (Mendes Guimarães-Beelen, 2006). This high concentration of the phenolic compounds, mainly condensed tannins, may reduce the availability of nitrogen that is necessary for rumen microbial growth cause of the formation of tannin-protein complexes (Molan et al., 2001; Osuga et al., 2005). It is known that high concentration of condensed tannins in leaves decreased the nutrient utilization and digestibility and $\mathrm{N}$ retention (Kumar and Vaithiyanathan, 1990; Mueller-Harvey and McAllan, 1992, Silanikove et al., 1996; Piluzza et al., 2013).

It is consider that a concentration of this compound at $3-4 \%$ dry weight can have positive effect on digestion (Robbins et al., 1998). Vitti et al. (2005) reported that tannins concentration between 2-4\% of DM is beneficial for digestion and a concentration above $5 \%$ resulted harmful for metabolism. However, these limits in tannin concentration must not generalized while others points of view related to plant may be taken into account. There was a decrease in leaves CT concentration from spring to autumn in the two leguminous species $R$. psendoacacia and $A$. fruticosa. Similar results have been found for $O$. viciifolia (Berard et al., 2011) and Acacia sp. (Salem, 2005). According to Singh et al. (1997) and Joseph et al. (1998) enzymes responsible for the production of CT in these species probably have decreased their activity as the plant matures. In addition, Skogsmyr and Fagerstrom (1992) reported that plants use more the soluble carbohydrates for their growth and seed production, than for tannins production, which has higher metabolic cost. However, $C$. arborescens and $M$. alba had very low tannins concentration both in spring and autumn. On the contrary, higher concentration in $A$. unedo was observed with the advanced maturation of the leaves. Kokten et al. (2012) reported similar findings for other Mediterranean shrub species.

The results of the present study provide evidence than the concentration of phenols through maturity is speciesdependent. Several factors may affect the concentration of $\mathrm{CT}$ in leaves. The quantity of CT to the foliage could vary according to the genotype (Baldwin et al., 1987) and their concentration and extractability changes with season and plant maturity (Hagerman, 1988; McMahon et al., 2000; Salem, 2005). Moreover, differences in the analytical procedures for tannins determination could lead to large variations in tannin concentration (Makkar, 2003b). Inconsistencies could be also due to sampling and climatic effect on foliage growth and plant nutrient accumulation (Salem, 2011). All the above factors alone or in combination had an effect on the nutritive value of the foliage as a livestock feed. The knowledge of tannins 
432 concentration due to seasonality could be useful for rangeland management practices to improve the ruminants' welfare and production. Thus, fodder species as $R$. pseudoacacia, A. fruticosa (Papachristou et al., 1999) and $M$. alba (Parissi, 2003) could be integrated in silvopastoral systems or used as supplement feed during autumn.

\section{Conclusions}

According to the findings of this study, the impact of maturation on the type and concentration of phenols and tannins is species-dependent. Based on their chemical composition, IVDMD and the concentration of condensed tannins, the investigated browse species could be ranked as follows: $M$. alba $>R$. pseudoacacia $>C$. arborescens $>A$. fruticosa $>A$. unedo. The nutritive value of stems was generally lower compared to leaves. In particular, $M$. alba seems to be a valuable feed resource for ruminants. The decreased tannins concentration in leguminous species $R$. pseudoacacia and $A$. fruticosa during autumn can result useful for utilize these species as valuable feed for livestock. However, this perspective needs to be confirmed also by an in vivo digestibility trial.

\section{References}

Al-Masri MR (2013). An in vitro nutritive evaluation of Medicago arborea as affected by growth stage and cutting regimen. Livestock Research Rural Development 25:77.

Amiri F, Mohamed Shariff AR (2012). Comparison of nutritive values of grasses and legume species using forage quality index. Songklanakarin Journal of Science and Technology 34:577-586.

AOAC (2002). Official methods of analysis, $17^{\text {th }} \mathrm{ed}$. Association of Official Analytical Chemists. Washington DC.

Bakshi MPS, Wadhwa M (2004). Evaluation of forest tree leaves of semihilly arid region as livestock feed. Asian-Australasian Journal of Animal Sciences 17:777-783.

Baldwin IT, Schultz JC, Ward D (1987). Patterns and sources of leaf tannin variation in yellow birch (Betula allegheniensis) and sugar maple (Acer saccharum).Journal of Chemical Ecology 13:1069-1078.

Ball DM, Collins M, Lacefield GD, Martin NP, Mertens DA, Olson KE, Putnam DH, Undersander DJ, Wolf MW (2001). Understanding forage quality. American Farm Bureau Federation. Publication 1-01, Park Ridge, Illinois.

Bansi H, WinaE, Matitaputy PR, TufarelliV(2014). Evaluation of Zapoteca tetragona forage as alternative protein source in ruminants' feeding. Italian Journal of Animal Science 13:147-150.

Barakat NA, Laudadio V, Cazzato E, Tufarelli V (2013). Potential contribution of Retama raetam (Forssk.) Webb \& Berthel as a forage shrub in Sinai, Egypt. Arid Land Research and Management 27:257271.

Barry TN, McNabb WC (1999). The implications of condensed tannins on the nutritive value of temperate forages fed to ruminants. British Journal of Nutrition 81:263-272.

Beyene T (2009). Assessment of livestock feed resources, feeding systems and rangeland condition in Assosa Zone, Benishangul-Gumuz Region. MSc thesis, Hawassa University, Hawassa, Ethiopia.

Berard NC, Wang Y, Wittenberg KM, Krause DO, Coulman BE, McAllister TA, Ominski KH (2011). Condensed tannin concentrations found in vegetative and mature forage legumes grown in western Canada. Canadian Journal of Plant Science 91:669-675.

Blair RM, Short HL, Burkart LF, Harelli A, Whelan JB (1981). Seasonality of nutrient quality and digestibility of three southern deer browse species. USDA. Southern Forest Experimental Station pp 50-161.

Cheeke PR (1992). Black locust forage as an animal feedstuff. In: Hanover JW, Miller K, Plesko S (Eds). Proceedings International Conference on Black Locust: Biology, Culture \& Utilization. Michigan, USA pp 252258.

Cordese R, Cabrol C, Habtemariam K, Dulor J (1991). Exploitation d' une garique a chene kermes (Quercus coccifera) et Brachypode (Brachypodium ramosum) par des ovins et des caprins. Proceedings IV International Rangeland Congress. Montpellier, France pp 616-618.

Corleto A, Cazzato E, Ventricelli P, Cosentino SL, Gresta F, Testa G, Maiorana M, Fornaro F, De Giorgio D (2009). Performance of perennial tropical grasses in different Mediterranean environments in southern Italy. Tropical Grasslands 43:129-138.

Delgado DC, Galindo J, González R, González N, Scull I, Dihigo L, Cairo J, Aldama AI, Moreira O (2012). Feeding of tropical trees and shrub foliages as a strategy to reduce ruminal methanogenesis: studies conducted in Cuba. Tropical Animal Health and Production 44:10971104 .

Dwi Yulistiani Z, Jelan A, Liang JB, Yaakub H, Abdullah N (2015). Effects of supplementation of mulberry (Morus alba) foliage and urea-rice bran as fermentable energy and protein sources in sheep fed urea-treated rice straw based diet. Asian-Australasian Journal of Animal Sciences 28:494 501.

Evans JR (1989). Photosynthesis and nitrogen relationship in leaves C3 plants. Oecologia 78:9-19.

Gilboa N, Perevolotsky A, Landau S, Nitsan Z, Silanikove N (2000). Increasing productivity in goats grazing Mediterranean woodland and scrubland by supplementation of polyethylene glycol. Small Ruminant Research 38:183-190.

Glyphis JP, Puttick GM (1988). Phenolics in some southern African Mediterranean shrubland plants. Phytochemistry 27:743-752.

Griffin JL, Jung GA (1983). Leaf and stem quality of big blue stem and switchgrass. Agronomy Journal 75:723-726.

Harris LE (1970). Nutrition research techniques for domestic and wild animals. Vol 1.Harris LE.Logan, UT pp 5501-5505.

Hagerman $\mathrm{AE}$ (1988). Extraction of tannins from fresh and preserved leaves. Journal of Chemical Ecology 14:453-461.

Hajer A, Lopez S, Chermiti A (2004). Nutritional characterization of some Mediterranean forestry resources. In: Mosquera-Losada M, Riguerio A, McAdam J (Eds). Silvopastoralism and Sustainable Land Management pp 137-139.

Holechek JL, Pieper RD, Herbel CH (1989). Range Management Principles and Practices. Prentice Hall Publ, Co, Englewood Cliffs, NJ.

Jamala GY, Tarimbuka I, Moris L, Mahai D, AdamawaS (2013). The scope and potentials of fodder trees and shrubs in agroforestry. IOSR Journal 
of Agricultural and Veterinary Science 5:1-17.

Joseph R, Tanner G, Larkin P (1998). Proanthocyanidin synthesis in the forage legume Onobrychis viciifolia - a study of chalcone synthase, dihydroglavonol 4-reductase and leucoanthocyanidin 4-reductase in developingleaves. Australian Journal Plant Physiology 25:271-278.

Kamalak A (2006). Determination of nutritive value of a native grown shrub, Glycyrrbiza glabra L. using in vitro and in situ measurements. Small Ruminant Research 64:268-278.

Khazaal K, MarkantonatosX, NastisA, Ørskov ER (1993). Changes with maturity in fibre composition and levels of extractable polyphenols in Greek browse: Effect on in vitro gas production and in sacco dry matter degradation. Journal of the Science of Food and Agriculture 63:237-244.

Kokten K, KaplanM, Hatipoglu R, Saruhan V, Cinar S (2012). Nutritive value of Mediterranean shrubs. The Journal of Animal and Plant Sciences 22:188-194.

Koukoura Z, Nastis AS (1994). Tannin content of selected fodder trees and shrubs and their effect on in vitro digestibility. Options Mediterraneennes 4:117-128.

Kramer PJ, Kozlowski TT (1979). Physiology of woody plants. Academic Press, Florida.

KumarR, Vaithiyanathan S (1990). Occurrence, nutritional significance and effect on animal productivity of tannins in tree leaves. Animal Feed Science and Technology 30:21-38.

McSweeney CS, Kennedy PM, John A (1988). Effect of ingestion of hydrolysable tannins in Terminalia oblongata on digestion in sheep fed Stylosanthes hamata. Australian Journal of Agricultural Research 39:235-244.

Makkar HPS, Bluemmel M, Borowy NK, Becker K (1993). Gravimetric determination of tannins and their correlations with chemical and protein precipitation methods. Journal of the Science of Food and Agriculture61:161-165.

Makkar HPS (2003a). Effects and fate of tannins in ruminant animals, adaptation to tannins, and strategies to overcome detrimental effects of feeding tannin-rich feeds. Small Ruminant Research 49:241-256.

Makkar HPS (2003b). Quantification of tannins in tree and shrub foliage: A laboratory manual. Dordrecht, the Netherlands, Kluwer Academic Press.

Manousidis T, Kyriazopoulos AP, Parissi ZM, Abraham EM, Korakis G, Abas Z (2016). Grazing behavior, forage selection and diet composition of goats in a Mediterranean woody rangeland. Small Ruminant Research145:142-153.

McDonald PR, Edwards A, Greenhalgh JF, Morgan CA (1995). Animal Nutrition, 5th edition. Longman, United Kingdom.

McMahon LR, McAllister TA, Berg BP, Majak W, Acharya SN, Popp JD, Coulman BE, Wang Y, Cheng KJ (2000). A review of the effects of forage condensed tannins on ruminal fermentation and bloat in grazing cattle. Canadian Journal of Plant Science 80:469-485.

Mendes Guimarães-Beelen TT, Berchielli R, Beelen J, Filho A, Gisele de Oliveira $S$ (2006). Characterization of condensed tannins from native legumes of the Brazilian northeastern semi-arid. Scientia Agricola 63:522-528.

Mero RN, Uden P (1997). Promising tropical grasses and legumes as feed resources in central Tanzania I. Effect of different cutting patterns on production and nutritive value of six grasses and six legumes. Tropical Grasslands 31:549-555.

Min BR, FernandezJM, Barry TN, McNabb WC, Kemp PD (2001). The effect of condensed tannins in Lotus corniculatus upon reproductive efficiency and wool production in ewes during autumn. Animal Feed Science and Technology 92:185-202.

Molan AL, Attwood GT, Min BR, McNabb WC (2001). The effect of condensed tannins from Lotus pedunculatus and Lotus corniculatus on the growth of proteolytic rumen bacteria in vitro and their possible mode of action. Canadian Journal of Microbiology, 47:626-633.

Moore JE (1970). Procedures for the two-stage in vitro digestion of forages. Nutrition research techniques for domestic and wild animals. Harris LE, Utah State Univ, Logan.

Mueller-Harvey I, McAllan AB (1992). Tannins: Their biochemistry and nutritional properties. Advances in Plant Cell Biochemistry and Biotechnology 1:151-217.

NRC (1981). Nutrient requirements of domestic animals, No 15: Nutrient requirements of goats. Washington DC, USA, Nat Acad Sci.

NRC (1985). Nutrient Requirements of Sheep, Gth rev edn. Washington DC,USA: Nat Acad Sci.

Osuga IM, Abdulrazak SA, Ichinohe T, Fujihara T (2005). Chemical composition, degradation characteristics and effect of tannin on digestibility of some browse species from Kenya harvested during the wet season. Asian Australasian Journal of Animal Sciences 18: 5460.

Papachristou TG, Papanastasis VP (1994). Forage value of Mediterranean woody fodder species and its implication to management of silvopastoral systems for goats. Agroforestry Systems 27:269-82.

Papachristou TG Nastis AS (1996). Influence of deciduous broadleaved woody species in goat nutrition during the dry season in Northern Greece.Small Ruminant Research 20:15-22.

Papachristou TG, Platis PD, Papanastasis VP, Tsiouvaras CN (1999). Use of deciduous woody species as a diet supplement for goats grazing Mediterranean shrublands during the dry season. Animal Feed Science and Technology 80:267-279.

Parissi ZM (2001). Effect of clipping density and frequency on production and quality of ligneous species. PhD Thesis. University of Thessaloniki, School of Forestry and Natural Environment.

Parissi ZM, Karameri E, Abraham EM, Kyriazopoulos AP, Petridis A (2014). Impact of maturation on extractable polyphenols in leguminous fodder species. Options Méditerranéennes 109:219-222.

Parissi ZM (2003). Effect of clipping intensity on forage production and quality of Morus alba L. during the summer period. Proceedings of the $3^{\text {nd }}$ Panhellenic Rangeland. Congress Karpenisi pp 293-299 (in Greek).

Paul H, Makkar S, Dawra RK, Singh B (1991). Tannin levels in leaves of some oak species at different stages of maturity. Journal of the Science of Food and Agriculture 54:513-519.

Piluzza G, Sulas L, BullittaS (2013). Tannins in forage plants and their role in animal husbandry and environmental sustainability: a review. Grass and Forage Science 69:32-48.

Porter LJ, Hrstich LN, Chan BG (1986). The conversion of procyanidins and prodelphinidins to cyaniding and delphinidin. Phytochemistry 25:223-230.

Pootaeng-on Y, Kimsri, N, Sooksom S, Tangchaitam S, Chiangmai Na P 
434

(2015). Condensed tannins in some tropical legumes residue. Silpakorn University Science and Technology Journal 9:51-60.

Provenza FD (1995). Postingestive feedback as an elementary determinant of food selection and intake in ruminants. Journal of Range Management 48:2-17.

Ramirez-Restrepo TN, Barry N, Lopez-Villalobos PD, Kemp B, Harvey TG (2005). Use of Lotus corniculatus containing condensed tannins to increase reproductive efficiency in ewes under commercial dryland farming conditions. Animal Feed Science and Technology 121:23-43.

Rana KK, Wadhwa M, Bakshi MPS (2006). Seasonal Variations in Tannin Profile of Tree Leaves. Asian-Australasian Journal of Animal Science 19:1134-1138.

Robbins CT, Hanley TA, Hagerman AE, Hjeljord O, Baker DL, Schartz CC, Mautz WW (1987). Role of tannins in defending plants against ruminants: reduction in protein availability. Ecology 68:98-107.

Rogler JC, Sell DR (1984). Effect of stage, maturity and tannin content on nutritional quality of low and high tannin sorghum. Nutrition Reports International 6:1281-1287.

Roukos C (2016). Seasonal and altitudinal variations in nutritional quality of kermes oak (Quercus coccifera L.) in northwest Greece and extensive goat farming. Bulgarian Journal of Agricultural Science 22:804-814.

Rubanza CDK, Shem MN, Otsyina R, Nishino N, Ichinohe T, Fujihara T (2003). Content of phenolics and tannins in leaves and pods of some Acacia and Dichrostachys species and effects on in vitro digestibility. Journal of Animal and Feed Sciences 12:645-663.

Salem AZM (2005). Impact of season harvest on in vitro gas production and dry matter degradability of Acacia saligna leaves with inoculum from three ruminant species. Animal Feed Science and Technology 123124:67-79.

Salem AZM (2011). Plant-Phytochemicals in Animal Nutrition. Hauppauge, NY, NovaScience Publishers.

Sallam SMAH, Bueno ICS, Godoy PB, Nozella EF, Vitti DMSS, Abdalla AL (2010). Ruminal fermentation and tannins bioactivity of some browses using semi-automated gas production technique. Tropical and Subtropical Agroecosystems 12:1-10.

Schultz JC, Nothnagle PJ, Baldwin IT (1982). Individual and seasonal variation in leaf quality of two northern hardwood tree species. American Journal of Botany 69:753-759.

Salawu MB, Acamovic T, StewarfCS, Roothaert RL (1999). Composition and degradability of different fractions of Calliandra leaves, pods and seeds. Animal Feed Science and Technology 77:181-199.

Shenkute B, Hassen A, Assafa T, Amen N, Ebro A (2012). Identification and nutritive value of potential fodder trees and shrubs in the mid rift valley of Ethiopia.Journal of Animal and Plant Sciences 22:1126-1132.

Silanikove N, Gilboa A, Nitsan Z, Perevolotsky A (1996). Effect of a daily supplementation of polyethylene gycol on intake and digestion of tannin-containing leaves (Quercus calliprinos, Pistacia lentiscus and Ceratonia siliqua) by goats. Journal of Agricultural and Food Chemistry 44:199-205.

Singh S, Mc Callum J, Gruber MY, Towers GHN, Muir AD, Bohm BA, Koupai-Abyazani MR, Glass ADM (1997). Biosynthesis of flavan-3-ols by leaf extracts of Onobrychis viciifolia. Phytochemistry 44:425-432.

Singh B, Todaria NP (2012). Nutrients composition changes in leaves of Quercus semecarpifolia at different seasons and altitudes. Annals of Forest Research 55:189-196.

Skogsmyr I, Fagerström T (1992). The cost of anti-herbivory defence: An evaluation of some ecological and physiological factors. Oikos 64:451457.

Solomon M (2001). Evaluation of selected multipurpose trees as feed supplements in teff (Eragrotis tef) straw based feeding of Menz Sheep. PhDThesis, Berlin, Germany.

Steel RGD, Torrie JH (1980). Principles and Procedures of Statistics. New York, USA, McGraw-Hill, $2^{\text {nd }}$ edn.

Tilley JA, Terry RA (1963). A two-stage technique for the in vitro digestion of forage crop.Journal of British Grassland Society 18:104-111.

Van Soest PJ (1982). Nutritional Ecology of the Ruminant. O\&B Books, Corvallis, OR.

Van Soest PJ, Robertson JB, Lewis BA (1991). Methods for dietary fiber, neutral detergent fiber and non starch polysaccharides in relation to animal nutrition. Journal of Dairy Science 74:3583-3597.

Vitti DMSS, Abdalla AL, Bueno ICS, Silva Filho JC, Costa C, Bueno MS, ... Mueller-Harvey I (2005). Do all tannins have similar nutritional effects? A comparison of three Brazilian fodder legumes. Animal Feed Science and Technology 119:345-361. 